\title{
"COM MÃO NOTURNA E DIURNA": LUÍS DE CAMÕES E OUTROS ESCRITORES PORTUGUESES NOS ROMANCES DE MACHADO DE ASSIS DA SEGUNDA FASE
}

Marcelo Sandmann ${ }^{*}$

\section{Retornando a Horácio}

Vos exemplaria Graeca nocturna versate manu, versate diurna.'

onsultado pelos Pisões, pai e dois filhos acerca dos problemas gerais que envolvem a arte literária e o gênero dramático em específico, Horácio acabaria por escrever em resposta um dos textos fundamentais da poética clássica. A sua Epistula ad Pisones (Epístola aos Pisões), ou

* Universidade Federal do Paraná

1 TRINGALI, Dante. A arte poética de Horácio. São Paulo: Musa, 1993. p. 20. Edição da Epístolu aos Pisĩes, do poeta latino Horácio, com o texto original em latim seguido de tradução para o português, notas e comentários analíticos. 
ainda Ars poetica (Arte poética), como ficou também conhecida, desfia longamente, entre gracejos e ironias, formulações peremptórias e sisudas, todo um decálogo sobre o fazer literário.

No que diz respeito aos autores a serem seguidos, Horácio é definitivo: "Vocês versem os modelos gregos com mão noturna e diurna."2

Ciente de que os romanos deviam muito mais a sua glória ao uso das armas que ao uso da língua, ${ }^{3}$ Horácio vem chamar a atenção para a urgência de se voltar aos antigos escritores gregos, tidos por ele e outros importantes poetas da sua geração ${ }^{4}$ como modelos insuperáveis de realização e excelência em todas as artes. Os gregos - e pairando acima de todos o sempre indiscutível Homero - compõem um cânone fundamental a ser conhecido e seguido.

Segundo Horácio, um autor que se queira digno desse nome precisa ter uma aguda consciência dos textos dos autores exemplares. Escreve com os olhos postos na obra daqueles que tem por mestres, com a memória impregnada pelo húmus fértil da sua leitura.

Para um poeta que defendia o trabalho exaustivo com a palavra, o burilar e reburilar até chegar-se à forma perfeita, ${ }^{5}$ a leitura cuidadosa e repetida dos autores de eleição se impunha, portanto, como tarefa axial dentro do próprio processo criativo.

Ler e escrever, reler e reescrever combinam-se num mesmo e fundamental gesto.

2 ARISTÓTELES; HORÁCIO; LONGINO. A poética clássica. 5. ed. Introd. de Roberto de Oliveira Brandão e trad. de Jaime Bruna. São Paulo: Cultrix, 1992. Trata-se da tradução para o português da citação em latim do texto de Horácio transcrito como epígrafe. A tradução de Jaime Bruna pareceu-me mais simples e clara que a de Dante Tringali, que diz por sua vez o seguinte: "Vós, volvei os modelos gregos com māo noturna, volvei com mão diurna."

3 ld., op. cit., p. 63. A esse respeito, podemos ler em tradução o seguinte: "Não seria mais poderoso o Lácio pela bravura e gloriosos feitos de guerra do que pela língua, se não entediasse o demorado trabalho da lima."

4 Horácio viveu entre 65 e 8 a.C. Outro contemporâneo seu, Virgílio, poeta latino fundamental, viveu por sua vez entre $70 \mathrm{e} 19 \mathrm{a}$.C. Junto com outros autores, defendiam a necessidade de se retomar os antigos modelos gregos, opondo-se assim àqueles que queriam se restringir aos modelos anteriores da própria tradição literária nacional.

5 Horácio diversas vezes aproxima metaforicamente o trabalho poético, eminentemente intelectual, ao trabalho artesanal. Referindo-se a ele, fala, por exemplo, no "demorado trabalho da lima", insiste na necessidade de se reter "o poema que não tenha sido apurado em longos dias por muita rasura, polido dez vezes até que uma unha bem aparada não sinta asperezas", ou ainda de se "desfazer os versos mal torneados e repô-los na bigorna". Cf. ARISTÓTELES; HORÁCIO; LONGINO. Op. cit., p. 63 e 67. 


\section{Horácio e os clássicos renascentistas portugueses}

Horácio será um autor de grande influência durante todo o Renascimento e enquanto durar a hegemonia dos princípios clássicos na arte européia, e a sua Epistula ad Pisones se constituirá leitura obrigatória para os autores classicizantes.

No quinhentismo português, um poeta tão importante como Sá de Miranda, justamente o introdutor da medida nova em Portugal, ${ }^{6}$ dirá, por exemplo, $\mathrm{cm}$ soneto em que defende o ideário clássico recém chegado:

Ando co'os meus papéis em diferenças;

são preceitos de Horácio - me dirāo;

em al não posso, sigo-o em aparenças. ${ }^{7}$

Mas quem mais extensamente glosará o texto horaciano será António Ferreira na sua "Carta XII", endereçada a Diogo Bernardes. ${ }^{8}$ Usando o mesmo expediente do poeta latino, Ferreira escreve sua epístola como resposta a Bernardes, que, em busca do douto conselho, teria instado o amigo a discorrer sobre o fazer literário. É nesse sentido que lemos os seguintes versos da carta:

Mas tratarei contigo amigamente
Do conselho que pedes; juízo, e lima
Tem em si todo humilde, e diligente.

De cabo a rabo, o que teremos é praticamente a direta transposição das principais idéias da Epistula ad Pisones.

6 Sá de Miranda retorna do estrangeiro em 1527, depois de ter estado na Itália e na Espanha, de onde trará as novidades do dolce stil nuovo e da efervescência classicizante então vivida nesses paises. Os novos temas e formas serīo conhecidos como medida wova, em oposição à agora chamada medida velha, a maneira lírica peninsular medieval. O ano de 1527 tem sido tradicionalmente assinalado, por esse motivo, como baliza inaugural do classicismo renascentista em Portugal.

7 MIRANDA, Francisco Sá de. Obras completas. v. 1. Lisboa: Sá da Costa, 1942. p. 303. Soneto intitulado "(Ao Príncipe D. João) A terceira vez, mandando-lhe mais obras".

8 FERREIRA, António. Poemas lusitanos. v. 2. Lisboa: Livraria Sá da Costa, 1940. p. $102-110$.

$9 \quad$ lbid., p. 104. 
António Ferreira revela-se portanto um assíduo leitor de Horácio, seguindo de muito perto seus passos. É a partir justamente da leitura do autor canônico que vai se gerar o texto do novo autor. Ferreira lê e escreve - reescreve Horácio. E os conselhos muito próximos acerca do ler e do escrever, bebidos no mestre latino, serão repassados ao seu interlocutor Bernardes:

É necessário ser um tempo mudo!

Ouvir, e ler somente: que aproveita

Sem armas, com fervor cometer tudo?

E logo a seguir:

Do bom escrever, saber primeiro é fonte.

Enriquece a memória de doutrina

Do que um cante, outro ensine, outro te conte. ${ }^{10}$

O cânone não se restringirá agora somente aos antigos escritores gregos, mas incorporará também os clássicos latinos e a poesia italiana desde Dante e Petrarca, sem deixar de lado os castelhanos italianizantes contemporâneos.

\section{Camões e o cânone clássico}

É em resposta afirmativa à leitura desse cânone que vai se construir boa parte da obra do principal nome do quinhentismo português: Luís de Camões.

Em célebre passagem do décimo e último canto de Os lusíadas, na antepenúltima estrofe do poema, em interlocução com o rei D. Sebastião, Camões declarava:

Nem me falta na vida honesto estudo,

Com longa experiência misturado, Nem engenho, que aqui vereis presente, Cousas que juntas se acham raramente.

10 FERREIRA, op. cit., p. 105.

11 CAMÕES, Luís de. Os lusíadas. 3. ed. Org. de Emanuel Paulo Ramos. Porto: Porto Editora, 1985. p. 355. 
Se ainda hoje é incerto e objeto de polêmica o modo como teria se dado efetivamente a formação literária do poeta (o "honesto estudo" a que se refere), certamente não fica difícil perceber o seu grande conhecimento do cânone literário do tempo, conhecimento exaustivamente explicitado em sua obra. ${ }^{12}$

Camões, assim como os clássicos portugueses seus contemporâneos, mas de uma forma ainda mais obsessiva, faz questão de deixar assinalados os rastros de suas leituras em meio à confecção dos textos.

Em Os lusiadas, por exemplo, quase não há episódio significativo da história geral portuguesa ou da história da viagem de Vasco da Gama que não seja posto imediatamente em paralelo com a história, a literatura e a mitologia greco-romanas (sobretudo). Para tudo Camões encontra referência possível em seus modelos, e a explicita. Mesmo que muitas vezes o paralelo surja com o intuito óbvio de exaltar a superioridade do episódio luso em detrimento dos episódios antigos, é claro que estamos diante de uma estratégia retórica que não diminui a grande reverência com que são tratados os intertextos canônicos. Mesmo que de modo impactante Camões vá dizer logo no início da sua epopéia:

Cesse tudo o que a Musa antiga canta, Que outro valor mais alto se alevanta. ${ }^{13}$

É a "Musa antiga" quem vai oferecer os modelos fundamentais para o seu canto, ${ }^{14}$ é ela quem vai continuar falando e vivendo através dele.

Camões também relê e reescreve a tradição literária, parte dos seus paradigmas para executar a sua obra individual. Mas Camões, de modo vigoroso, pede que ela se cale, para em meio ao impossível silêncio revelar a sua voz. E não é à toa que ele se tornará o autor canônico por excelência para a literatura em língua portuguesa (aquém e além-mar) dos séculos seguintes. Esse esforço de absorver as linhas mestras de toda uma longa tradição, concentrá-las em sua própria obra, ao mesmo tempo em que procura propiciar uma contrapartida pessoal e local à altura, indicando a partir dessa tensão as diretrizes para a produção posterior, é que dá a ele o sentido mais amplo e menos datado da expressão "autor clássico".

12 Cf., por exemplo, RAMALHO, Américo da Costa. Sobre a cultura de Camöes. Coliquio / Letras, Lisboa, n. 47, jan. 1979.

13 CAMÕES, op. cit., p. 71.

14 O "novo canto, heróico, e generoso, nunca ouvido dos nossos bons passados", que é como Antônio Ferreira se referia às potencialidades latentes nas formas da "medida nova". Cf. FERREIRA, op. cit., v. 1, p. 115. 


\section{Camões e a tradição literária posterior}

Camões vai se tornar leitura obrigatória para as gerações posteriores. Seja pela índole patriótica do seu poema épico, ideologicamente comprometido com o imperialismo luso, espelho literário festejado pelo poder oficial; seja pelo uso exemplar da língua portuguesa, que vai fazer dele modelo perpetuado nas classes escolares, cartilhas e sebentas; seja pela experiência mais propriamente humana e poética bebida em sua poesia, inspiração para tantos outros autores, Camões será versado "com mão noturna e diurna".

Temas e formas do seu lirismo serão retomados, em chave amplificada, pelos poetas peninsulares seiscentistas. A ele retornarão os árcades quando quiserem sanear a poesia dos excessos do barroco. E mesmo quando o classicismo será posto em questão já no início do séc. XIX, é um Camões romântico quem regressará como personagem no poema homônimo de Almeida Garrett. Aliás, será justamente o seu Camões, longo poema narrativo em decassílabos brancos, publicado em 1825, o texto que virá a ser celebrado como introdutor do romantismo em Portugal. ${ }^{15}$ Mais ao final do séc. XIX, a comemoração do Centenário de Camões, em 1880 (tricentenário da morte do poeta), capitaneada por Teófilo Braga, grandemente festejada no país, vem atestar a difusão do poeta e do mito por amplos setores da sociedade portuguesa. A poesia das últimas décadas do século em Portugal, de Antero de Quental a Eugênio de Castro, não deixará de evocar Camões como um de seus modelos fundamentais.

Igualmente grande vai se revelar a presença do poeta português na tradição da literatura brasileira. Gilberto Mendonça Teles, em estudo importante sobre o tema, Camões e a poesia brasileira, ${ }^{16}$ palmilha com cuidado as veredas da presença camoniana entre nós, desde a literatura colonial, passando pelas principais correntes poéticas do séc. XIX (romantismo, parnasianismo e simbolismo), num Brasil já politicamente independente, até chegar à poesia modernista.

Cada instante e cada autor lerá Camões a seu modo. E aproveitará o impacto fortificante dessa leitura para escrever e reescrevê-lo em alguma distinta direção.

15 Massaud Moisés, na esteira da tradiçāo, assim o considera. Cf. MOISÉS, Massaud. A literatura portuguesa. 27. ed. Sũo Paulo: Cultrix, 1994. p.112-113. Já para António Saraiva e Óscar Lopes, esta obra de Garrett, visivelmente distante do arcadismo clássico, não teria tido sequiência imediata na literatura portuguesa. Estes autores preferem, portanto, considerar o ano de 1836 como baliza inicial para o romantismo, quando se publica $A$ voz do profeta, de Alexandre Herculano, e Ciúmes do bardo e Noite do castelo, de António Feliciano de Castilho, que atestam já o predomínio definitivo do gosto romîntico entre os portugueses. Cf. LOPES, Óscar; SARAIVA, António José. História da literatura portugutesa. 12. ed. Porto: Porto Editora, 1982. p. 719.

16 TELES, Gilberto Mendonça. Camöes e a poesia brasileira. 3. ed. Rio de Janeiro: Livros Técnicos e Científicos, 1979. 


\section{Camões e Machado}

Gostaria de desenvolver a partir de agora algumas considerações iniciais sobre a presença de Camões na obra de Machado de Assis, outro escritor já devidamente absorvido çomo autor canônico pela tradição literária. A chave ideal de entrada para esse universo de indagações é justamente entender Machado como um leitor assíduo de Camões, e alguém que, de modo explícito, confere ao clássico português o estatuto de autor modelar, debruçando-se sobre a sua obra "com mão noturna e diurna", na mais uma vez repetida expressão de Horácio.

Machado é um leitor voraz, que incorpora ao seu texto as marcas de suas leituras (e isso é mais do que evidente na obra da maturidade, onde textos e autores surgem explicitamente citados, de forma paródica ou não, com reverência ou franca irreverência). Não seria de todo forçado entrever aí justamente uma impregnação desse modo de se relacionar com a tradição já explicitado por Horácio na sua Epistula ad Pisones. O escritor reconhece um universo de autores canônicos e toma esse universo como referência para a construção da sua própria obra. Se a intenção paródica, sempre muito forte em muitos dos textos de Machado, poderia insinuar uma possível corrosão do cânone, vale lembrar que Camões, de modo imperativo, pedia que a "Musa antiga" cessasse o seu canto, para que ele pudesse enunciar o seu. Mas assim como a "Musa antiga" continuava cantando através do novo canto, ela necessariamente vai sempre revelar o rosto sob a máscara cáustica da paródia.

Um capítulo na bibliografia de Machado de Assis a ser mais extensamente escrito é o das suas leituras portuguesas, e entre elas o da sua leitura da obra de Luis de Camões. ${ }^{17}$

Quem mapeou a presença do autor português na poesia de Machado é o já citado Gilberto Mendonça Teles. ${ }^{18}$ Ele indica alguns poemas do escritor brasileiro que deixam entrever essa presença, quer em versos aproveitados no corpo dos seus próprios textos, quer aproveitados em epígrafe: "Elegia", em Crisálidas; ${ }^{19}$ "Un vieux pays", em Falenas; ${ }^{20}$ e "A derradeira injúria", em

17 Muito se tem escrito sobre as influências recebidas por Machado de Assis. Eugênio Gomes escreveu, por exemplo, todo um livro sobre as "influências inglesas", vistas por ele como decisivas para a constituição do "modo machadiano" da segunda fase (cf. GOMES, Eugênio. Machado de Assis: influências inglesas. Rio de Janeiro: Pallas/Brasilia: INL, 1976). Prefiro falar aqui em leituras de deterninado autor a usar o termo influências, entre outros motivos, porque creio que este pode induzir à idéia de que a presença da obra de um autor na de outro tenha se dado de forma inconsciente e involuntária.

is TELES, op. cit., p. 205-206.

19 ASSIS, Machado de. Poesias completas. Rio de Janeiro: Nova Aguilar, 1992. (Obras completas de Machado de Assis, v. 3, p. 25-27).

20 Ibid., p. 52. 
Poesias coligidas - Dispersas. ${ }^{21}$ Indica ainda outros textos conscientemente construídos sobre o modelo camoniano: a série de quatro sonetos intitulada "Camōes", cm Ocidentais; ${ }^{22}$ e "O Almada", 23 poema de natureza herói-cômica escrito em oito cantos.

Fora do âmbito da poesia, um importante texto ainda assinalado por Mendonçai Teles é a peça Tu só, tu, puro amor... ${ }^{24}$ (cujo título é fragmento de verso extraído de Os lusíadas, III, 119), cm que Camões aparece como personagem. peça escrita e encenada em 1880, por ocasião dos festejos do tricentenário da morte do poeta português. Como o próprio Machado deixa evidente na "Advertência" que antecede o texto, ${ }^{25}$ trata-se de peça encomendada pelo Gabinete Português de Leitura para engrossar as homenagens realizadas na capital do país a Luís de Camões. Publicado no ano seguinte, em 1881, portanto no mesmo ano $\mathrm{cm}$ que virá a público o seu romance fundamental Memórias póstumas de Brís Cubas, este texto dramático de Machado, sua última incursão pelo gênero, será a despedida da maneira primeira do autor. ${ }^{26}$ É ainda do mesmo

21 ASSIS, Machado de. Poesias completas. Rio de Janeiro: Nova Aguilar, 1992. (Obras completas de Machado de Assis, v. 3, p. 305-311.

22 Hiid., p. 164-165.

23 Hid., p. 230-282.

24 IJ., Tiu sí, II. purrs anor... (Ed. fac-símile). Rio de Janeiro: Biblioteca Nacional, 1980. Encontra-se inserido nessia ediçio um ensaio introdutório de Gilberto Mendonça Teles intitulado "Machado c Canóxs". Essa ediçä́o fac-similada da peça de Machado comemora os quatrocentos anos da morte de Caunōes e os cem anos dos festejos em Portugal e no Brasil do importante tricentenário do poeta.

25 Transcrevo aqui a parte inicial da advertência contida na edição aciuna assinalada, modernizando a ortografia, jí que ela, aléın de indicar a intenção comemorativa do texto, apresenta de modo sumbirio também o seu conteúdo: "A composição que ora se reimprime foi escrita para as festas organizadas, nesta capital, pelo Gabinete Português de Leitura, c representada no teatro D. Pedro II. O desfecho dos annores palacianos de Camöes e de D. Catarina de Ataíde é o objeto da comédia, desfecho que deu lugar à subseqüente aventura de África, e mais tarde à partida para a Índia, d'onde o poeta devia regressir um dia com a imortalidade nas māos. Não pretendi fazer um quadro da corte de D. João III, nem sei se o pernnitian as proporçōes mínimas do escrito e a urgência da ocasiāo. Busquei, sim, haver-ıne de maneira ciłe o poxta fosse contemporîneo de scus amores, nāo lhe dando feições ćpicas, e, por assim dizer, postumas."

26 Não deixa de ser sugestivo que Camões apareça assim como personagem com contornos românticos tanto no texto que tem sido considerado por muitos como o marco inicial do romantismo em Portugal (o já referido Camōes, de Almeida Garrett, publicado em 1825), portanto da prime ira manifestação do romantismo em literatura de língua portuguesa, quanto num tex to como esse de Machado, já no crepúsculo do romantismo literário entre nós. Sugestivo ainda que o Camōes de Garrett é o que está voltando do exílio no Oriente, com o texto de Os lusíadas debaixo do braço, para enfrentar em Portugal as já míticas agruras do nảo reconhecimento do seu valor em vida, enquanto gue o Camoöes de Machado é o que, pelas suas também já mais do que mńticas peripécias amorosias, é condenado ao exílio, antevendo na hora da partida o destino literário glorioso que o esperia. 
ano de 1880, e com o mesmo propósito comemorativo, a redação dos quatro sonetos enfeixados sob o título "Camōes", já indicados acima.

Mas Machado não se revela leitor de Camōes somente nestes textos. Tu soi, tu, puro anor... é texto dramático escrito sob encomenda, para as comemoraçōes do tricentenário do poeta português, e por trás da sua relativa sensaboria, para além do Machado tradicionalmente considerado um escritor Jramático $s \mathrm{sm}$ muito brilho, talvez esteja o fato de estarmos aqui diante de um escrito excessivamente marcado pelo clima de celebração oficial. E a presença de Camões na poesia de Machado, justamente num escritor que faz a ponte para a poesia parnasiana, seria, em maior ou menor medida, inclusive de se esperar. ${ }^{27}$ Porém, encontrar essa presença num gênero como o romance, gênero alheio ao universo literário de Camões e ao classicismo tradicional, e nos romances da maturidade de Machado, é indício inequívoco da consistência e vitalidade de uma dedicada leitura.

\section{Escritores portugueses nos romances de Machado da segunda fase}

São os cinco romances da chamada segunda fase de Machado os que pretendo aqui abordar: Memórias póstumas de Brás Cubas, Quincas Borba, Dom Casmurro, Esaú e Jacó e Memorial de Aires.

Diversas vezes encontramos, explicitamente citados nesses romances, autores portugueses. ${ }^{28}$

27 Cr. BOSI, Alfredo ef al. Machado de Arsis. Sīo Paulo: Ática. 1982. Coleçäo Escritores Brasileiros - Antologia \& Estudos. p. 499. Bosi, na bibliografia comentada inserida ao final do volume. referindo-se à Histriria da literatura brasilcira. de Jose Veríssimo, no capítulo dedicado por este autor a Machado, sintetiza desta maneira o modo como Verissimo apreciava a sua poesia: "Como poeta, o seu mérito estaria no apuro da forma, que se ilustra, por exemplo, no uso que faz. do alexiundrino. metro recém-aclimado à língua portuguesa. Veríssimo encarece muito a correçäo prosódicia e gramatical dos versos juvenis de Machado e a contrapõe a desleixo dos últimos românticos. Preza igualmente o decoro e a contensio do poeta alheio a oratória e à pieguice da poesia brasileira dos anos de 60. Esses predicados de Machado e principalmente o seu trato comstante com os chissicos portugueses teriam feito dele um precursor e mestre dos pamasianos." (os grifos sĩo meus)

28 Como fonte de consulta sobre datas de nascimento e mone bem como sobre outras informaçós's literírias acerca de autores portugueses, estou utilizando a seguinte obra de referincia: MOISÉS, Massaud. Pequeno diciomário de literatura portuguesı. São Paulo: Culırix, 1981. 
Os autores mais remotos são os trovadores medievais Joham Zorro (séculos XIII e XIV) e D. Dinis (1261-1325), cujos versos servem de epígrafe ao Memorial de Aires. ${ }^{29}$

Entre os autores quinhentistas, além de Camões, que será comentado com maior detalhe a seguir, temos Bernardim Ribeiro e João de Barros.

Bernardim Ribeiro (1482? -1552?), autor da novela sentimental Menina e moça, surge mencionado três vezes. Em Quincas Borba: "Aí está Bernardim Ribciro; [...]". ${ }^{30}$ Indiretamente em Esaú e Jacó: "Mas aquela menina e moça [...]". " E em registro paródico no Memorial de Aires: "Confessei-Ihe que seriam mais adequadas se eu as resumisse em emendar Bernardim Ribeiro: 'Viúva e noiva me levaram da casa de meus pais para longes terras [...]"'.32

João de Barros (1496?-1570), nome fundamental da historiografia do Renascimento, é mencionado duas vezes. Em Dom Casmurro: "Um historiador da nossa língua, creio que João de Barros, [...]". ${ }^{33}$ E em Memorial de Aires: "Quando eu lia clássicos lembra-me que achei em João de Barros [...].".34

Alguns importantes autores barrocos são também mencionados.

O Padre Antônio Vieira (1608-1697) é referido uma única vez, em Memóricis póstumas de Brás Cubas: "Quem me dera agora o verbo solene de um Bossuet ou de um Vieira, para contar tamanha desolação!"35

Igualmente uma vez é referido D. Francisco Manuel de Melo (16081666), em Memorial de Aires: "Posso dizer com D. Francisco Manuel: 'Eu de meu natural sou miúdo e prolixo; o estar só e a melancolia, que de si é cuidadosa [...]"”.36

O Padre Manuel Bernardes (1644-1710) é citado três vezes. Em Memórias póstumas de Brás Cubas: "Esta idéia, rútila e grande, - trajada ao bizarro, como diria o Padre Bernardes, - esta idéia [...]." ${ }^{, 37}$ Em Quincas Borba:

29) ASSIS, Machado de. Memorial de Aires. São Paulo: Globo, 1997. Epígrafes. (Obras completas de Machado de Assis)

30) Id., Quincas Borba. São Paulo: Globo, 1997, cap. CXII, p. 151. (Obras completas de Machado de Assis)

31 Id., Escú́ e Jacó. São Paulo: Globo, 1997, cap. LIX, p. 123. (Obras completas de Machado de Assis). Menina e moça é justamente o título da famosa novela sentimental de Bermardim Ribeiro, cuja primeira edição data do ano de 1554.

32 Id., Memorial..., p. 145. A novela de Bernardim Ribeiro inicia assim: "Menina e moça me levaram de casa de meu pai para longes terras [...]." Cf. RIBEIRO, Bernardim. Obras completas. 4. ed. Lisboa: Sá da Costa, 1982. p. 1. v. 1: Menina e moça.

33 Id., Domn Casmurro. São Paulo: Globo, 1997, cap. CXVII, p. 181 (Obras completas de Machado de Assis)

34 Id., Memorial..., p. 126.

35 ASSIS, Machado de. Memórias pósttumas de Brás Cubas. São Paulo: Global, 1997. cap. LIX, p. 95. (Obras completas de Machado de Assis)

$36 \mathrm{ld}$., Memorial..., p. 37.

37 Id., Memórias póstumas..., cap. LIX, p. 94. 
"[...] todas as referências e histórias mentirosas de Rubião como que lhe davam saudades, - saudades de quê? - 'saudades do céu', que é o que dizia o Padre Bernardes do sentimento de um bom cristão." dado a letras clássicas, achou no Padre Bernardes esta tradução daquele salmo: "Alonguei-me fugindo e morei na soedade.",39

Dois autores do séc. XVIII são mencionados, os dois em Memórias póstumas cle Bras Cubas. Um deles é o autor dramático Antônio José da Silva, o Judeu (1705-1739): "O glosador vasculhava na memória algum pedaço literário e achou este, que mais tarde verifiquei ser de uma das óperas do Judeu. ${ }^{40}$ E o outro, o poeta Manuel Maria Barbosa du Bocage (1765-1805): "Imenso talento o do Bocage!",4!

E do séc. XIX, um único e muito importante nome: Almeida Garrett. Garrett (1799-1854) é mencionado no prólogo da 3." edição de Memórias póstumas de Brás Cubas: "Macedo Soares, em carta que me escreveu por esse tempo, recordava amigamente as Viagens na minha terra. ${ }^{, 2}$ É preciso lembrar que, já desde a primeira edição, em "Ao leitor", texto introdutório às Memórias póstumas..., Machado citava explicitamente Sterne e Xavier de Maistre como modelos para o seu romance, sem aludir ainda ao Garrett de Viagens na minha terra. ${ }^{43}$ É só no referido prólogo que isso vai se corrigir, quando Machado reconhecerá a presença do escritor português, sobretudo em função desse seu importante romance, ao lado dos dois estrangeiros: "Toda essa gente viajou: Xavier de Maistre à roda do quarto, Garrett na terra dele, Sterne na terra dos outros. De Brás Cubas se pode talvez dizer que viajou à roda da vida." ${ }^{\text {,4 }}$ Garrett surge ainda citado em Quincas Borba: "Desapontamento? Já o clegante Garrett não achava outro termo para tais sensações, e nem por ser inglês o desprezava., ${ }^{45}$

38 ASSIS, Quincas..., cap. CLIV, p. 208.

39) Id., Escaí..., cap. XXXII, p. 65.

40 ld.. Memórices póstumuss..., cap. XII, p. 27.

41 Ibid.. cap. XII, p. 25.

42 llbial., prólogo da 3., ed.

43 Viagens na min/a terra, uma das principais obras de Almeida Garrett e certamente o seu romance mais importante, foi publicado pela primeira vez em 1846. Ali também se deixa entrever a influência dos mesmos escritores lembrados por Machado na abertura de Memórias póstumas... Saraiva e Lopes vão dizer a esse respeito: "A efabulação aparece por entre a ramagem das impressōes de viagem e digressōes de toda a ordem de que são feitas as Viagens na minha terra, segundo o modelo da Viagem sentimental de Sterne (1787) e da Viagem à roda do meu quarto de Xavier de Maistre (1795)." (SARAIVA e LOPES, História da literatura..., p. 753)

44 ASSIS, Memórias póstumas..., prólogo da 3." ed.

45 ld.. Quincas..., cap. VI, p. 72. Garrett viveu como exilado político durante algum tempo na Inglaterra, onde entrou em contato mais estreito com o importante romantismo literário inglês. São recorrentes as incorporaçōes em sua obra de vocábulos de origem anglo-saxônica, fato para o qual aponta a passagem macliadiana em foco. 


\section{Camões nos romances de Machado da segunda fase}

Mas o autor português mais presente nesses romances é o poeta Luís de Camões (1525-1580). Em todos eles encontramos freqüentes alusões à sua obra, desde a citação explícita de textos e a referência direta ao seu nome, até sugestões um pouco mais veladas, para além da epiderme do texto, a exigir um esforço de leitura interpretativa que se permita algum vôo de imaginação. Porém, gostaria de me restringir aqui às referências mais explícitas, mais palpáveis e inequívocas.

Em Memórias póstumas de Brás Cubas, lemos a seguinte passagem: "Lembra-me que desviei o rosto e baixei os olhos ao chão. Recomendo este gesto às pessoas que não tiverem uma palavra pronta para responder, ou ainda às que recearem encarar a pupila de outros olhos. Em tais casos, alguns preferem recitar uma oitava de Os lusíadas, outros adotam o recurso de assobiar a Norma; eu atenho-me ao gesto indicado; é mais simples, exige menos esforço." ${ }^{46}$

Em Quincas Borba, numa das exposições da doutrina filosófica do Humanitismo pela personagem que dá título ao romance, encontramos a seguinte formulação: " - Humanitas é o princípio. Há nas cousas todas certa substância recôndita e idêntica, um princípio único, universal, eterno, comum, indivisível e indestrutível, - ou, para usar a linguagem do grande Camões:

Uma verdade que nas cousas anda, Que mora no visíbil e invisibil. ${ }^{47}$

Os versos citados foram extraídos de uma das elegias de Camões, a que começa com as palavras

Se quando contemplamos as secretas

Causas, por que o mundo se sustenta

Em algumas edições enumerada como a quinta elegia. Os versos citados são, precisamente, os versos 26 e 27 desse poema. ${ }^{48}$

46 ASSIS, Memórias póstumas..., cap. CIII, p. 151.

47 Il., Quincas..., cap. VI, p. 8.

48 CAMÕES, Luís de. Lírica. Introdução e notas de Aires da Mata Machado Filho. Belo Horizonte: Itatiaia/São Paulo: Edusp, 1982. p. 281-286. Nesta edição, a referida elegia surge enumerada como a quinta da série. 
Convém assinalar que este texto camoniano é uma de suas mais belas e entusiasmadas profissões de fé nos dogmas do catolicismo e um ataque ao paganismo e às formulações filosóficas da antiguidade clássica ("a falsa teologia e povo escuro, / que nesta só verdade tanto errou"49). A idéia de um Deus criador onipotente, de uma Santíssima Trindade, de um Deus-Filho que se fez carne para morrer pela remissão dos homens na cruz, da pureza e santidade de Maria, etc., são alguns dos elementos dogmáticos recuperados poeticamente por Camões em sua elegia. Estão, portanto, na contramão do Humanitismo de Quincas Borba.

Na seqüência desse fragmento machadiano, vamos ler justamente o seguinte: "Pois essa substância ou verdade, esse princípio indestrutível é que é Humanitas. Assim the chamo, porque resume o universo, e o universo é o homem." ${ }^{50}$ Machado, via Quincas Borba, cita Camões, mas para recuperá-lo num contexto que trai o contexto camoniano de origem.

Em Dom Casmurro, são diversas as passagens em que podemos entrever o poeta português.

Ainda no começo do romance, através da palavra do seu narrador Dom Casmurro, Machado dedica alguns bons capítulos para apresentar as personagens Capitu e Bentinho ainda jovens e todos os episódios que vão culminar no seu enamoramento. A certa altura, Dom Casmurro, na reminiscência de momentos tão importantes da sua adolescência, define finalmente o olhar com que Capitu parecia misteriosamente fitar Bentinho, cuja caracterização, dada um pouco antes pelo agregado José Dias, "olhos de cigana oblíqua e dissimulada", 51 estava ecoando ainda na consciência do rapaz. Depois de procurar detidaménte por uma imagem adequada, é esta a que vai ser empregada: "Olhos de ressaca? Vá, de ressaca. É o que me dá idéia daquela feição nova. Traziam não sei que fluido misterioso e enérgico, uma força que arrastava para dentro, como a vaga que se retira da praia, nos dias de ressaca." 52

Logo adiante, Bentinho está penteando os cabelos de Capitu, demoradamente, deixando-se envolver pelo encantamento e deleite daquele contato, quando a imagem dos "olhos de ressaca" retorna, agora com um novo dado: "Se isto vos parecer enfático, desgraçado leitor, é que nunca penteastes uma pequena, nunca pusestes as mãos adolescentes na jovem cabeça de uma ninfa... Uma ninfa! Todo eu estou mitológico. Ainda há pouco, falando dos seus olhos de ressaca, cheguei a escrever Tétis; risquei Tétis, risquemos ninfa; digamos

49 CAMÕES, Lírica, p. 282.

so ASSIS, Quincas..., p. 8.

5I Id., Dom Casmurro..., cap. XXXII, p. 53.

52 lbid., p. 54. 
somente uma criatura amada, palavra que envolve todas as potências cristãs e pagãs." 5.3

Capitu aparece à consciência de D. Casmurro como uma ninfa, e justamente a ninfa marinha Tétis, ninfa sugerida pelas próprias imagens marinhas concentradas na metáfora empregada para definir-lhe os olhos.

E Tétis, não por acaso, é a ninfa marinha do famoso episódio camoniano do Gigante Adamastor. É no canto V de Os lusíadas, entre as estâncias 37 e 72, que se desenrola o celebrado episódio da desilusão amorosa do gigante, outrora titã navegador em contenda com a armada de Netuno, que se deixara enamorar pela beleza de Tétis, mas fora por ela enganado. Perdida a guerra dos gigantes para os deuses olímpicos, Adamastor é transformado em um monte, justamente - Cabo Tormentório, depois Cabo da Boa Esperança. A lembrança de sua amada Tétis e do logro de que fora vítima são as águas do mar a cercar o cabo:

[...] e, por mais dobradas mágoas, Me anda Tétis cercando destas águas. ${ }^{54}$

Se a ninfa Tétis surge no romance de Machado aproximada à personagem Capitu, não scria excessivo ir um pouco adiante e entrever um mesmo liame entre o Adamastor e D. Casmurro. Ambos estão a narrar os seus infortúnios amorosos. Sob a superfície mais aparente do texto de Machado, ecoa um belo motivo camoniano.

Ainda em Dom Casmurro, outro motivo de Camões, igualmente extraído de Os litsíadas, surge aproveitado.

Encontramo-nos no cap. CV, "Os braços", e Bentinho e Capitu estão em seus primeiros anos de casados. Uma das distraçöes do casal são os bailes, nos quais Capitu cxibe sempre triunfalmente seus encantos. E entre esses encantos, destacam-se sobremaneira os braços, que arrisca levar despidos algumas vezes, para o crescente aborrecimento de Bentinho. Porém, advertida do constrangimento do marido, Capitu deixa de mostrá-los assim. É com estas palavras que se encerra o capítulo: "[...] a outros [bailes] foi, mas levou-os meio vestidos de escumilha ou não sei que, que nem cobria nem descobria inteiramente, como o cendal de Camões." 55

53 ASSIS, Dom Casmurro..., p. 55.

54 CAMÖES, Os lusiadas..., V, 59, p. 207.

55 ASSIS, Dom Casmurm..., cap. CV, p. I63. 
Para se entender devidamente a comparação, é preciso voltar a Os lusíadas, no canto II, e ler a partir da estância 33. Desenvolve-se ali uma das mais intensas cenas mitológicas camonianas, o episódio em que Vênus, atendendo às súplicas dos navegadores portugueses, de quem é protetora, sobe para junto de Júpiter, para que o deus supremo do panteão olímpico interceda em favor dos seus protegidos. Para melhor convencê-lo, a ele que é seu pai e também seu amante, num jogo de sedução explícita, Vênus, belíssima, apresenta-se nua, cingida apenas por um "delgado cendal", que mais parece revelar que cobrir:

Cum delgado cendal as partes cobre

De quem vergonha é natural reparo;

Porém nem tudo esconde nem descobre

$\mathrm{O}$ véu, dos roxos lírios pouco avaro. ${ }^{56}$

É como estratégia de sedução, portanto, que Vênus, a deusa do amor, simula cobrir a nudez. É como uma dissimulada seguidora da deusa, a se utilizar de um mesmo estratagema, que D. Casmurro quer capturar retrospectivamente aqui Capitu.

E, finalmente, há ainda em Dom Casmurro uma quarta passagem em que Camões é rapidamente citado: "Nem digas que nos faltam Homeros, pela causa apontada em Camões; não senhor, faltam-nos, é certo, mas é porque os Príamos procuram a sombra e o silêncio.", 57

Em Esali e Jacó encontramos duas referências. Quando Natividade, a mãe dos gêmeos Pedro e Paulo, chega aos quarenta anos, é com estas comparações que o narrador de Machado sintetiza-lhe a pacata biografia: "Era a isenção, era o ter atravessado a vida intacta e pura. O Cabo das Tormentas converteu-se em Cabo da Boa Esperança e ela venceu a primeira e a segunda mocidade, sem que os ventos the derribassem a nau, nem as ondas a engolissem." ${ }^{58}$ O narrador alude então às não correspondidas requestas de que ela fora objeto al gurnas vezes: "Não negaria que alguma lufada mais rija pudera levar-lhe a vela do traquete, como no caso de João de Melo, ou ainda pior, no de Aires, mas foram bocejos de Adamastor." Para então encerrar: "Concertou a vela depressa e o gigante ficou atrás cercado de Tétis, enquanto ela seguiu o caminho

56 CAMŌES, Os lusíadas..., II, 37, p. 108.

57 ASSIS, Dom Casmurro..., cap. CXXV, p. 190.

58 Id., Esali..., cap. XIX, p. 43. As duas outras citações contidas neste parágrafo foram extraídas da mesina fonte e lugar. 
da Índia. Agora lembrava-se da viagem próspera. Honrava-se dos ventos inúteis e perdidos. A memória trazia-lhe o sabor do perigo passado."

A trajetória existencial de Natividade é comparada a uma viagem às Índias, porém uma viagem quase sem transtornos e perigos. Os únicos episódios que poderiam tê-la posto em risco, de natureza sentimental, foram ultrapassados sem maiores consequiências. As solicitações amorosas não correspondidas surgem como um Gigante Adamastor cercado de Tétis que ficou para trás na viagem. O Cabo das Tormentas - as palpitações da juventude - fora devidamente dobrado, transformou-se agora em pacificado Cabo da Boa Esperança.

É de se ressaltar aqui a imagem do "Gigante Adamastor cercado de Tétis", que concentra em si todos os perigos de uma vivência amorosa entrevista como problemática, e que retrospectivamente pode iluminar o já comentado aproveitamento do mesmo episódio camoniano que Machado faz em Dom Casinurro.

Ainda em Esalí e Jacó, encontramos a seguinte passagem: "Nem sempre os filhos reproduzem os pais. Camões afirmou que de certo pai só se podia esperar tal filho, e a ciência confirma esta regra poética. Pela minha parte creio na ciência como na poesia, mas há exceções, amigo."59

O fragmento camoniano aqui referido encontra-se em Os lusíadas, III, 28, quando é pela primeira vez apresentado aquele que será o primeiro rei de Portugal, Afonso Henriques, segundo Camões, herdeiro do brilho guerreiro de seu pai, o Conde D. Henrique:

Ficava o filho em tenra mocidade,

Em quem o pai deixava seu traslado,

Que do mundo os mais fortes igualava,

Que de tal pai tal filho se esperava. ${ }^{60}$

E, finalmente, em Memorial de Aires encontramos uma última citação: "A conversação foi andando com eles, ao longo da praia, onde o mar, indo e vindo, era como se os convidasse a meterem-se nele até desembarcar 'no porto da ínclita Ulisséia', como diz o poeta.",61

O "poeta" aqui, como não poderia deixar de ser, é Camões, que faz uso dessa expressão ao referir-se a Lisboa no Canto IV, estância 84 , de Os lusiadas, ${ }^{62}$ no momento em que a armada de Vasco da Gama se prepara para a partida em

59 ASSIS, Esctí.., cap. XXIX, p. 58.

60 CAMÕES, Os lusiadas..., III, 28, p. 136.

61 ASSIS, Memorial..., p. 146-147.

62 CAMÕ̉ES, Os lusíadas..., IV, 84, p. 186. 
direção às Índias. Lisboa, lendariamente, teria sido fundada pelo herói grego Ulisses, a quem deveria inclusive o nome. Em Machado, as personagens Tristão e Fidélia estão às voltas com a sua partida definitiva para Lisboa, deixando no Brasil seus pais adotivos, Dona Carmo e Aguiar. A partida dos navegadores portugueses, no episódio camoniano, surge envolta em grande dor e aflição por parte dos familiares que ficam. Estabelece-se assim um sugestivo liame entre os textos.

\section{Concluindo}

Procurei arrolar aqui todos os autores portugueses citados por Machado nos seus romances da maturidade e as passagens específicas onde isso se evidencia. Destaquei entre eles Luís de Camões, revelando ainda o interesse do escritor brasileiro por este poeta em outros diferentes momentos da sua obra. Com relação a Camões ainda, arrisquei, para os casos mais significativos, uma leitura em contraste, mostrando como Machado vai ler os seus textos e aproveitar motivos.

Creio que não é gratuitamente, como se tratasse de um simples ornamento, da exibição de um virtuosismo erudito, que Machado cita Camões e os portugueses, entre tantos outros autores. Esse uso funcional de outros textos, essa costura sutil que amarra um tecido a outro tecido, tem um papel importante na economia das obras que só a leitura contrastiva pode evidenciar.

Revela ainda, certamente, o grande apreço de Machado pelos grandes nomes da tradição literária. Machado elege um cânone e trabalha em íntimo diálogo com esse universo referencial. Entre os autores que a ele pertencem, os portugueses, e entre eles sobretudo Camões, não se encontram em posição secundária. É com "mão noturna e diurna", horacianamente, que ele procurará versá-los.

\section{RESUMO}

Este artigo trata da presença de escritores portugueses, com destaque para Luís de Camōes, nos romances de Machado de Assis da segunda fase.

Palavras-chave: Machado de Assis e a literatura portuguesa, Machado de Assis e Luís de Camões, literatura comparada: literaturas brasileira e portuguesa. 


\section{ABSTRACT}

This article focuses on the presence of Portuguese writers, particulary Luís de Camōes, on Machado's post-1880 novels.

Key words: Machado de Assis and Portuguese literature, Machado de Assis and Luis de Camões, compared literature: Portuguese and Brazilian literatures.

\section{REFERÊNCIAS BIBLIOGRÁFICAS}

ARISTÓTELES; HORÁCIO; LONGINO. A poética clássica. 5. ed. Trad. de Jaime Bruna. São Paulo: Cultrix, 1992.

ASSIS, Machạdo de. Tu só, tu, puro amor... Rio de Janeiro: Biblioteca Nacional, 1980.

Ed. fac-símile. . Memórias póstumas de Brás Cubas. São Paulo: Global, 1997. (Obras completas de Machado de Assis). Assis).

Dom Casmurro. São Paulo: Globo, 1997. (Obras completas de Machado de Assis).

. Esaú e Jacó. São Paulo: Globo, 1997. (Obras completas de Machado de Assis). . Memorial de Aires. São Paulo: Globo, 1997. (Obras completas de Machado de Assis).

. Poesias completas. Rio de Janeiro: Nova Aguilar, 1992. (Obras completas de Machado de Assis, v. 3).

BOSI, Alfredo et al. Machado de Assis. São Paulo: Ática, 1982. Coleção Escritores

Brasileiros - Antologia \& Estudos.

CAMÕES, Luís de. Lirica. Introdução e notas de Aires da Mata Machado Filho. Belo Horizonte: Itatiaia/São Paulo: Edusp, 1982.

. Os lusiadas. 3. ed. Org. de Emanuel Paulo Ramos. Porto: Porto Editora, 1985.

FERREIRA, António. Poemas lusitanos. v. 1 e 2. Lisboa: Sá da Costa, 1940.

GOMES, Eugênio. Machado de Assis: influências inglesas. Rio de Janeiro: Pallas/ Brasília: INL, 1976.

LOPES, Óscar; SARAIVA, António José. História da literatura portuguesa. 12. ed. Porto: Porto Editora, 1982.

MIRANDA, Sá de. Obras completas. v. 1 e 2. Lisboa: Sá da Costa, 1942.

MOISÉS, Massaud. A literatura portuguesa. 27. ed. São Paulo: Cultrix, 1994. . Pequeno dicionário de literatura portuguesa. São Paulo: Cultrix, 1981. 
RAMALHO, Américo da Costa. Sobre a cultura de Camões. Colóquio / Letras, Lisboa, n. 47 , jan. 1979.

RIBEIRO, Bernardim. Obras completas. 4. ed. Lisboa: Sá da Costa, 1982. v. 1: Menina e moça.

TELES, Gilberto Mendonça. Camões e a poesia brasileira. 3. ed. Rio de Janeiro: Livros Técnicos e Científicos, 1979.

Machado e Camões. In: ASSIS, Machado de. Tu só, tu, puro amor... Rio de Janeiro: Biblioteca Nacional, 1980. Ed. fac-simile.

TRINGALI, Dante. A arte poética de Horácio. São Paulo: Musa, 1993. Texto original em latim, com tradução, notas e estudo literário. 